\title{
Sciendo
}

ECONOMICS AND CULTURE 17(1), 2020

DOI: $10.2478 /$ jec-2020-0009

\section{PRODUCT BRANDING AND CONSUMER LOYALTY IN TELECOMMUNICATION INDUSTRY}

\author{
Kowo Solomon Akpoviroro', Akinbola Olufemi Amos², Akinrinola Olalekan Oladipo3, \\ Adegbite Ganiu Adewale ${ }^{4}$ \\ ${ }^{1}$ Department of Business Administration, Kwara State University, Malete Nigeria \\ ${ }^{2}$ Department of Business Administration, Federal University of Agriculture, Abeokuta \\ ${ }^{3}$ Department of Accounting, Caleb University Lagos, Nigeria \\ ${ }^{4}$ Department of Marketing, Ogun State Institute of Technology Igbesa, Nigeria
}

\begin{abstract}
Research Purpose. With fierce competition and saturated marketing in Nigeria, telecom operators must work hard to reduce cost, win new customers, and most importantly, retain the existing ones. The aim of the study was to examine the relationship between product branding and consumer loyalty in the Nigerian telecommunication industry.

Design / Methodology / Approach. This research employed survey research design. Primary data was adopted with the aid of a questionnaire administered to the customers of three major telecommunication companies in Nigeria (MTN, AIRTEL and GLOBACOM) residing in Lagos State. The population of the study was 172, the sample size was 120 , which were determined using the simple computation method. The study made use of statistical tools that include: analysis of variance (ANOVA), correlation efficient and Statistical Packages for Social Sciences (SPSS) Version 17.0.

Findings. The results of this study confirm with the existing literature that product branding as a feature has a significant effect on product. The study found out that there exists a significant relationship between product branding and consumer loyalty in the Nigerian telecommunication industry. Consequently, from the practical perspective, telecommunication firms should expand their network coverage, improve the quality of service and provide better access to other networks within and outside Nigeria.

Originality / Value / Practical implications. The study seeks to contribute to existing literature on product branding and customer loyalty. The paper contributes in clarifying that telecom providers in Nigeria must make product branding as a very important aspect of its marketing strategy and it must be given a serious approach, because it goes a long way to determine the success or failure of the product offer to the market, the firm in question and its ability to achieve consumer loyalty
\end{abstract}

Keywords: Product Branding; Consumer Loyalty; Choice and Patronage; Telecommunication Industry.

JEL codes: M31; L96.

\section{Introduction}

The Nigerian telecommunication industry is experiencing stiff competition and it is the duty of every player in the industry to develop a good marketing strategic plan that will enable it win a good portion of the market (Okpara, 2002; Anyanwu, 2003). Most potential customers already have a telephone line or two, unlike the initial stage of the deregulation of the industry. It is not enough to get customers in the industry, but also converting them to loyal customers (Adeleke \& Suraju, 2012). The real competition here now is not mainly on getting new customers but retaining the existing ones (Olakunori, 1999). If any company must survive in the industry, it must shift its marketing strategy from just winning new customers to retaining the existing ones (Keller, 2003; Choi, 2013). Lee et al. (2012) describe customer loyalty as follows: 'Customer loyalty is a composite of a number of qualities. It is driven by 
customer satisfaction, yet it also involves a commitment on the part of the customer to make a sustained investment in an ongoing relationship with a brand or company. Customer loyalty is reflected by a combination of attitudes (intention to buy additional products or services from the same company, willingness to recommend the company to others, commitment to the company demonstrated by a resistance to switching to a competitor) and behaviours (repeat purchasing, purchasing more and different products or services from the same company, recommending the company to others). Nebo (2004) stated that customer loyalty is one major attribute that brands need to thrive in the market place. If customers are loyal to a brand, they become ambassadors by mouthing good stories about the brand (Kumar, 2002). Alireza and Aran (2011) posit that the basic truth is when customers are happy; they go to a large extent to promote a good image for the brand. Customer loyalty is all about relevance and meaning throughout every customer touch point. It is all about making the brand experience a more intimate relationship with the customers (Anjum et al., 2013). To achieve this (brand loyalty), the companies in the industry must pay more attention to its product branding. Many definitions of branding have been offered by different authors and a lot of reasons have also been deduced by different authorities as justifications for the adoption of branding as a marketing strategy. Branding is a fixation of special and unique image or attribute to a particular product, which makes it to be exceptional among other products in the eyes and minds of consumers (AMA, 2011; Gronhold et al., 2000; Ehikwe, 2005). The above definition of branding means that a brand has an added value to the physical product beyond the core product. These may be aesthetic, emotional, psychological and philosophical values that are embedded in the minds and hearts of consumers (Ahmad, Hassan \& Rajput, 2015). Based on the definition, a brand is a product and the value-added personify it beyond the core product. This statement infers that branding identifies the product for the consumer and relates it to branding and product design. Phan and Lan (2001) captured the very essence of branding when they described it as an integral and intimate part of a product strategy. Lee (2013) opined that a product is not complete until it is given a name, mark or symbol. Branding has been identified as one of the major tools in the hands of firms to increase consumer loyalty (Kuo et al., 2013). Branding is a fixation of special and unique image or attribute to a particular product, which makes it to be exceptional among other products in the eyes and minds of consumers (Ehikwe, 2005). In view of this context, two research objectives were proposed for the study: (i) To examine whether product branding and features have a significant relationship on customer patronage for telecommunication products; (ii) To determine the relationship between product branding and consumer loyalty in the Nigerian telecommunication industry.

\section{Literature Review}

\section{The Concept of Product Branding, Product Level and its Importance}

A product is everything that is considered inclusive of satisfaction and utilities that the buyer obtains in the purchase (Malik et al., 2012). According to Ching (2007), a product is the basic ingredient in the exchange process. The expectation that satisfaction will be realized through exchange is what a product represents; it is the focus bringing buyers and sellers together to make exchange. The marketer see it as a good or service that most closely meets the requirements of a particular market or segment and yield enough profit to justify its continued existence, while the economist sees it as goods (physical) and services (intangible), while has the ability to give utility to the consumer or user (Edward, 2010; Evanschitzky \& Wunderlich, 2006). According to Kotler and Keller (2009), there are five different levels of product that must be well understood in order to produce a product that will satisfy the needs of the targeted market. Nebo (2004) classified product into four pairs: durable and non-durable categories -this classification reflects the life expectancy of a product; perishable and non-perishable ones - the factor of perishable ability here can be psychological as well as physical; and also as necessity and luxuries ones - necessity are essential, while luxuries are those that match wants more than needs; and finally, those product that are price elastic and those that are price inelastic. Marketers see the variation of products and brands as going through a life cycle that begins with commercialization and ends with removal from the market place. This is defined in terms of two dimension, sales volume and time (Juwan, 2011; Kotler, 2010; Chaudhuri, 2001; Reichheld, 2003). The product life cycle is divided into five stages: introduction or pioneering stage - here, product has not been accepted by the market; rapid growth or market acceptance stage - here, sales rise at an increasing rate as consumers accept and 
demand the product; slow growth or turbulence stage - here, sales climb high but at a decreasing rate; saturation or maturity stage - here, sales level off and everyone seems to have the product; decline or obsolescence stage - here, sales turn downward, profit usually decreases and competitors leave the scene (Choi et al., 2006; Keller, 2002; Back \& Packs, 2003).

Many definitions of branding have been offered by different authors and a lot of reasons have also been deduced by different authorities as justifications for the adoption of branding as a marketing strategy (Chung et al., 2006). What is more, the popularity of a brand has often been said to be a direct push for sales turnover (Dobers, 2009; Evanschitzky \& Wunderlich, 2006). Not minding the vagaries of definitions of branding, the fact still remains that it is an important aspect of every firm's marketing activity that cannot be overlooked. Branding has been said to be as important as a child's naming ceremony and as old as man/creation (Okpara, 2002; Ahmad, Hassan \& Rajput, 2015). Branding is a fixation of special and unique image or attribute to a particular product, which makes it to be exceptional among other products in the eyes and minds of consumers (Ehikwe 2005; Chakraborty \& Sengupta, 2014). From the above definition of branding, it means that a brand has an added value to the physical product beyond the core product. These may be aesthetic, emotional, psychological and philosophical values that are embedded in the minds and hearts of consumers. Based on the definition, a brand is a product and the value-added, which personifies it beyond the core product. Onah and Thomas (2004) identified the various types of brands as manufacturer's brand and private brands. They posited that branding helps to facilitate the performance of various other Marketing Management functions like New Product Introduction, Advertising and other Promotions, Pricing and so on. It is strongly speculated that most times, what consumers buy is name and not quality or functionality or performance. Djupe (2000) captured the very essence of branding when he described it as an integral and intimate part of a product strategy. This suggests that a product is not complete until it is given a name, mark or symbol. From the foregoing discussions, it is obvious that the essence of branding is to create a distinctive and unique product, whose name rings a bell and commands the influence of consumers positively in terms of one's purchase behaviour (Luo \& Bhattachanya, 2006; Fraering \& Minor, 2013). This against the backdrop for a bigger and more resonating name, for a better perceived name, certain consumers will be willing to pay a little more. Consequently, it is safe to extrapolate that branding distinguishes the product or service of a manufacturer(s) from that of other manufacturer(s) of the same or similar products. This distinctive element is particularly crucial for the repeat purchasers and first-time buyers or prospects of malt drinks. Van Auken (2007) compiled a list of characteristics of leading brands as follows: has very high awareness, increases customer loyalty, decreases price sensitivity, results in increased market share, especially for the target customers. In this list of characteristics, of great importance is that it reduces price sensitivity, commands customer loyalty and commands positive perception among consumers or customers. This goes to probably suggest why branding may influence consumer purchase behaviour. Levitt (1983) opined that branding is usually a way of distinguishing a company's product from the competing products. It should be an assumption that companies, particularly those starting new and those not sure of what the consumers' reaction to their products would be, would approach the branding exercise with a lot of ambivalence (De Bakker et al., 2005). The resultant name, term, sign, symbol or any combination is what comes out as the brand. This means that a brand can come in the form of a name or mark (Nebo, 2004; Kumar, 2002; Edward et al., 2010). Lee (2013) stated that branding helps to supplement advertising and personal selling. Branding seeks to provide a prospect that has been notified through advertising, the means of identifying the product in the market place. Therefore, brand name is another product attribute that can contribute to consumer acceptance of a product. It can be extended to refer to the visual features such as package, colour, typography design or slogan, which should assist in stimulating and maintaining demand (Kuo et al., 2013; Choi, 2013). A branded product once acceptable to the consumer can lead to brand loyalty, good brand image, and thus, greater market acceptance of such a product. Because branding adds to the value of products, market acceptance and achieve competitive edge over others market, designation of branding include brand name, brand mark, trade mark copyright, family branding, individual branding, manufacturers brand, distributor's brand, primary brand, secondary brands and so on (Reichheld, 2003; Adeleke \& Suraju, 2012). There is a need for differentiation that gives rise to the branding of products as mark of identification, differentiation and recognition in the presence of so many products that have similar outlook (Anyanwu, 2003; Olakunori, 1999). 


\section{$\underline{\text { Role of the Brand }}$}

The crucial role of branding according to Okpara (2002) can be captured from three perspectives: Consumers, Manufacturers and Intermediaries.

a. Consumers: For consumers, product branding does the followings:

i. It facilitates the identification and purchase of preferred product choices.

ii. It enthrones some status symbols on users of the product.

iii. Especially for new products, they can help in the first-hand evaluation of the products' likely suitability and quality, judging from who is the owner of the brand.

b. Manufacturers: Product branding to the manufacturers is vital in the following ways;

i. It affords a manufacturer on exclusive legal protection for his unique efforts and product features, from competitive parody.

ii. It is vital in differentiating and serving market segments of various purses, purposes and personalities.

iii. It facilitates the identification of a manufacturers' product on the retail shelves.

iv. It can provide a manufacturer with an avenue to escape the travails of price related competition

c. Intermediaries: These include the wholesalers, retailers, agents, jobbers and so on. A typical store, supermarket or distributor benefits from branding in the following ways:

i. The brands are usually advertised by the manufacturers, thereby making sales easier for intermediaries.

ii. It makes description and location of needed products by shoppers much easier.

iii. Promotional materials based on product brands are usually given as gifts to intermediaries.

\section{Customer Loyalty}

Alizera and Aram (2011) stated that customer loyalty is a composite of a number of qualities. It is driven by customer satisfaction, yet it also involves a commitment on the part of the customer to make a sustained investment in an ongoing relationship with a brand or company. Customer loyalty is reflected by a combination of attitudes (intention to buy again and/or buy additional products or services from the same company (Kumar, 2002; Malik et al., 2012; Dobers, 2009). Customer loyalty is one major attribute that brands need to thrive in the market place. When customers are loyal to a brand, they become ambassadors by mouthing good stories about the brand (Lee, 2013; Choi, 2013; AMA, 2011). It is a basic truth that when customers are happy, they go to a large extent to promote the good image for the brand (Gronhold et al., 2000). Customer loyalty is all about relevance and meaning throughout every customer touch point. It is all about making the brand experience a more intimate relationship with the customers (Minarti \& Segoro, 2014). Brand loyalty is the situation in which a consumer generally buys the same manufacturer-originated product or service repeatedly over time rather than buying from multiple suppliers within the category (Kuusik, 2007; Phan \& Lau, 2001).

\section{Methodology}

This research adopted the use of survey research design. The consumers will be purposefully selected, in which 172 consumers will be selected from the three firms. This will give all the consumers to have an equal opportunity of being selected. This is because the actual population of the consumers cannot be determined. Since it is usually not possible to study the entire larger population of telecom firms in Nigeria, the researcher will be choosing consumers of MTN, AIRTEL and GLOBACOM. The sample will be determined from various users of the three telecom firms. To this extent the sample size will be determined by a simple computation method. Therefore, an approximate sample size of 120 respondents will be used to conduct the research. For the purpose of this study, the secondary sources that will be used are journals, textbooks, reports and periodicals. The sample frame that will be used are the consumer of the selected Firms. The researcher employ stratified sampling and purposive sampling to 
select the respondents of the study. The Cronbach's Alpha will be used to assess the reliability of the data. The sampling validity will be used to access the validity of the data. It is a measure of validity obtained, to ensure that the measure covers the broad range of areas within the concept through a sample size under the study in order to achieve the research objective (Cresswell et al., 2003). The study made use of statistical tools that include: analysis of variance (ANOVA) and correlation efficient in testing hypotheses, wherever applicable. The responses from the questionnaire were sorted, coded and Statistical Packages for Social Sciences (SPSS) Version 17.0 was used for analysis.

Table 1. Distribution of respondents and response rate (Source: Field Survey 2018)

\begin{tabular}{|l|c|c|}
\hline Respondents Occupation & Questionnaire administered (sampled) & Percentage of total response (\%) \\
\hline GLOBACOM Consumer & 27 & 27.0 \\
\hline AIRTEL Consumer & 20 & 30.0 \\
\hline MTN Consumer & 53 & 53.0 \\
\hline Total & 100 & 100.0 \\
\hline Gender/Category & Questionnaire administered (sampled) & Percentage of total response (\%) \\
\hline Male & 46 & 46.0 \\
\hline Female & 54 & 54.0 \\
\hline Number of Returned & 100 & 16.7 \\
\hline Number of Not Returned & 20 & 100 \\
\hline $\begin{array}{l}\text { Total Number of } \\
\text { Questionnaires }\end{array}$ & 120 & \\
\hline
\end{tabular}

Table 2. The Descriptive statistics of Product Branding and Consumer Loyalty in the Telecommunication Industry (Source: Field Survey 2018)

\begin{tabular}{|l|l|}
\hline Product Branding Features and Customer Patronage for Telecommunication Products & Mean \\
\hline $\begin{array}{l}\text { Product branding and features determine customers' choice and patronage of } \\
\text { telecommunication products }\end{array}$ & 4.86 \\
\hline Product branding may influence consumer purchasing behaviour & 3.99 \\
\hline Most telecom firms use product branding as their promotional tool & 3.88 \\
\hline Product branding increases the level of productivity & 3.65 \\
\hline $\begin{array}{l}\text { Product branding is necessary for the survival of any business and its product, especially in the } \\
\text { highly competitive Nigerian telecommunication industry }\end{array}$ & 3.96 \\
\hline $\begin{array}{l}\text { There is a significant relationship between product branding features and customer patronage } \\
\text { for telecommunication products }\end{array}$ & 3.88 \\
\hline Product Branding and Consumer Loyalty in the Nigeria Telecommunication Industry & Mean \\
\hline $\begin{array}{l}\text { Customer loyalty helps to relate to the future purchase intention of the customer to } \\
\text { repurchase the desired product. }\end{array}$ & 3.89 \\
\hline $\begin{array}{l}\text { Product branding determines consumer's loyalty and a better branding leads to increased } \\
\text { customers loyalty. }\end{array}$ & 3.98 \\
\hline $\begin{array}{l}\text { Product branding helps customer to differentiate the product from other product in the same } \\
\text { industry. }\end{array}$ & 3.88 \\
\hline Product branding helps to make awareness of a product in the market & 3.76 \\
\hline Products branding are designed to satisfy customers according to their needs. & 3.92 \\
\hline
\end{tabular}




\section{Results}

Hypothesis One

$\mathrm{H}_{0}$ : There is no significant relationship between product branding features and customer patronage for telecommunication products..

$\mathrm{H}_{1}$ : There is a significant relationship between product branding features and customer patronage for telecommunication products.

Table 3. Correlation matrix (Source: Authors' computation)

\begin{tabular}{|c|c|c|c|}
\hline & & Product Branding & Product choice and customer patronage \\
\hline \multirow{3}{*}{$\begin{array}{l}\text { PRODUCT } \\
\text { BRANDING AND } \\
\text { FEATURES }\end{array}$} & Pearson Correlation & 1 & $0.203^{*}$ \\
\hline & Sig. (2-tailed) & & 0.043 \\
\hline & $\mathrm{N}$ & 100 & 100 \\
\hline \multirow{3}{*}{$\begin{array}{l}\text { CUSTOMER } \\
\text { PATRONAGE }\end{array}$} & Pearson Correlation & $0.203^{*}$ & 1 \\
\hline & Sig. (2-tailed) & 0.043 & \\
\hline & $\mathrm{N}$ & 100 & 100 \\
\hline
\end{tabular}

Result: Pearson Correlation Value of the hypothesis is 0.203 having the $r$ value of 0.001 (in which $p$ value is lesser than 0.01 ), it shows that the correlation result is considered to be significant at 0.05 level. This shows a correlation between the dependent and independent variables with the value of 0.203 at a significance level of 0.05 . Hence, it is concluded that there is a significant relationship between product branding features and customer patronage for telecommunication products. Therefore, the decision would be to reject the null hypothesis $\left(\mathrm{H}_{0}\right)$, and accept the alternative hypothesis $\left(\mathrm{H}_{1}\right)$

\section{Hypothesis Two}

$\mathrm{H}_{0}$ : There is no significant relationship between product branding and consumer loyalty in the Nigeria telecommunication industry.

$\mathrm{H}_{1}$ : There is a significant relationship between product branding and consumer loyalty in the Nigeria telecommunication industry.

Table 4. Model summary (Source: Authors' computation)

\begin{tabular}{|c|c|c|c|c|c|}
\hline Model & $\mathrm{R}$ & R Square & $\begin{array}{l}\text { Adjusted R } \\
\text { Square }\end{array}$ & $\begin{array}{l}\text { Std. Error of the } \\
\text { Estimate }\end{array}$ & Durbin-Watson \\
\hline 1 & $0.349^{\mathrm{a}}$ & 0.122 & 0.116 & 1.703 & 1.997 \\
\hline \multicolumn{6}{|c|}{ a. Predictors: (Constant), PRODUCT BRANDING } \\
\hline \multicolumn{6}{|c|}{ b. Dependent Variable: CONSUMER LOYALTY } \\
\hline
\end{tabular}


Table 5. ANOVA (Source: Authors' computation)

\begin{tabular}{|c|c|c|c|c|c|c|}
\hline \multicolumn{7}{|c|}{$\mathrm{ANOVA}^{\mathrm{a}}$} \\
\hline \multicolumn{2}{|c|}{ Model } & Sum of Squares & $\mathrm{D}_{f}$ & Mean Square & $\mathrm{F}$ & Sig. \\
\hline \multirow[t]{3}{*}{1} & Regression & 63.476 & 1 & 63.476 & 21.897 & $0.000^{\mathrm{b}}$ \\
\hline & Residual & 458.024 & 158 & 2.899 & & \\
\hline & Total & 521.500 & 159 & & & \\
\hline \multicolumn{7}{|c|}{ a. Dependent Variable: CONSUMER LOYALTY } \\
\hline
\end{tabular}

The result from the model summary table revealed that the extent to which the variance in customer loyalty can be explained by product branding is $12.2 \%$, that is, (R square $=0.122$ ). The ANOVA table shows the $\mathrm{F}_{\mathrm{cal}} 21.897$ at a significance level. The table shows that both variables are significant at a significance level of 0.01 .

Table 6. Regression coefficients (Source: Authors' computation)

\begin{tabular}{|c|c|c|c|c|c|c|}
\hline \multicolumn{7}{|c|}{ Regression Coefficients ${ }^{\mathrm{a}}$} \\
\hline & & \multicolumn{2}{|c|}{ Unstandardized Coefficients } & $\begin{array}{l}\text { Standardized } \\
\text { Coefficients }\end{array}$ & \multirow[b]{2}{*}{$\mathrm{T}$} & \multirow[b]{2}{*}{ Sig. } \\
\hline \multicolumn{2}{|c|}{ Model } & B & Std. Error & Beta & & \\
\hline \multirow[t]{2}{*}{1} & (Constant) & 10.617 & 1.504 & & 7.061 & 0.000 \\
\hline & Product branding & 0.396 & 0.085 & 0.349 & 4.679 & 0.000 \\
\hline
\end{tabular}

The coefficient table above shows the simple model that expresses the relationship between customer loyalty and discount. The model is shown mathematically as follows:

$y=\mathrm{a}+\mathrm{b} x$, where $y$ is customer loyalty and $x$ is discount, $\mathrm{a}$ is a constant factor and $\mathrm{b}$ is the value of coefficient. From this table, therefore, product branding $=10.617+0.396$ customer loyalty. It shows that both tested variables are at a significance level of 0.01 , which means that there exists a significant relationship between product branding and customer loyalty. Therefore, for every $100 \%$ increase in customer loyalty, product branding contributed $39.6 \%$.

The significance level below 0.01 implies that a statistical confidence of above $99 \%$. This implies that there is a positive significant relationship between product branding and customer loyalty. Thus, the decision would be to reject the null hypothesis $\left(\mathrm{H}_{0}\right)$, and accept the alternative hypothesis $\left(\mathrm{H}_{1}\right)$

\section{Conclusions}

The result of findings has shown that there is no significant relationship between Product choice and customer patronage for telecommunication products. Also, there exists a significant relationship between product branding and customer loyalty in the Nigerian telecommunication industry. The research shows that product branding and features such as coverage, quality of service, tariff, customers service, promotion, value added service and access to other networks determine customers' choice and patronage of these networks. Product diversification and innovation such as prepaid airtime, mobile banking, mobile internet, mobile cable TV, video conferencing, sim backup and improved caller tunes determine customers' choice and patronage of telecommunication products. The correlation coefficient 
reveals that product branding has a very strong positive relationship with consumer loyalty in the Nigerian telecommunication industry. This implies that product branding determines consumer's loyalty and a better branding leads to increased customer loyalty. From the research findings, the researcher therefore makes a conclusion that product branding is necessary for the survival of any business and its product, especially in the highly competitive Nigerian telecommunication industry. The focus has shifted from just only to get new customer to keeping the existing ones while looking for new ones, because that is the only way to succeed in the industry now. Therefore, the telecommunication firms in the industry in Nigeria, in order to maintain customer loyalty and increasing its profitability, must engage in quality product branding as this will help re-position its product offering and differentiate it from other competitors in the market place. This research recommends that:

Telecommunication firms should expand their network coverage and improve the quality of service they offer, because these are the major factors that affect customer loyalty.

Telecommunication providers in Nigeria must maintain a low and friendly tariff in order to increase customer loyalty and reduce brand switch.

Also, they must provide better access to other networks within and outside Nigeria, because this is another important factor that affects consumer loyalty.

\section{References}

Adeleke, A., \& Suraju, A. (2012). The determinants of customer loyalty in Nigeria's GSM market. International Journal of Business and Social Science, (3),14

Ahmad, J., Hussain, M., \& Rajput, A. (2015). Customer Loyalty Framework of Telecommunication Service Market. International Journal of Managing Value and Supply Chains,(6), 83.

Alireza, F., Ali, K., \& Aram, F. (2011). How quality, value, image, and satisfaction create loyalty at an Iran telecom. International Journal of Business and Management,( 6),8, 271.

Anjum, N., Rizwan, M., Khaleeq, M., \& Rasheed., H. (2013). Influence of Brand Loyalty in Telecommunication Sector in Pakistan. Journal of Public Administration and Governance, ( 3), 3, 188-202.

Anyanwu, A. (1999). Marketing Management, Benin City: Barioz Publishers.

Anyanwu, A. (2000). Dimensions of Marketing, 2nd. Ed., Owem: Avan Publication.

Anyanwu, A. (2003). Promotional Strategy, A schematic Approach, Owerri: Avan Global Publication.

Anyanwu, A. \& Okafor, A. (1995). The Practice of Marketing, Owerri: Ken Publishers.

Belk, R. (2001). Materialism and You, Journal of Research for Consumers Available from Internet: http wwwjrconsumers .com. 102

Back, K.., \& Parks, S. (2003). A brand loyalty model involving cognitive, affective, and conative brand loyalty and customer satisfaction. Journal of Hospitality \& Tourism Research, (4)27, 419-435.

Chaudhuri, M. (2001). The chain of effects from brand Trust and Brand Affect to Brand Performance: The Role of Brand loyalty'. Journal of Marketing, (2) 65, 81-94.

Ching, R. (2007). The effects of mobile customer relationship management on customer loyalty: brand image does matter'. Journal of Economic Psychology, (16), 311-329.

Chakraborty, S., \& Sengupta, K. (2014). Structural equation modelling of determinants of customer satisfaction of mobile network providers: Case of Kolkata, India. IIMB Management Review, (26)4, 234-248.

Choi, B., \& La, S. (2013). The impact of corporate social responsibility (CSR) and customer trust on the restoration of loyalty after service failure and recovery. Journal of Services Marketing, (27)3, 223-233.

Choi, D. H., Kim, C. M., Kim, S.-I., \& Kim, S. H. (2006). Customer loyalty and disloyalty in internet retail stores: its antecedents and its effect on customer price sensitivity. International Journal of Management, (23) 4, 925.

Chung, K.., Yu, J., Choi, M., \& Shin, J.. (2006). The Effects of CSR on Customer Satisfaction and Loyalty in China: The Moderating Role of Corporate Image. 
Creswell, J. W., PlanoClark, V., Gutmann, M., \& Hanson, E. (2003). Advanced mixed methods research designs. Handbook of mixed methods in social and behavioral research, 209-240.

DeBakker, F., Groenewegen, P., \& DenHond, F. (2005). A bibliometric analysis of 30 years of research and theory on corporate social responsibility and corporate social performance. Business \& Society, (3)44, $283-317$.

Dobers, P. (2009). Corporate social responsibility: management and methods. Corporate Social Responsibility and Environmental Management, (16)4, 185-191.

Djupe, P.A. (2000) 'Religious Brand Loyalty and Political Loyalties'. Journal for the Scientific Study of Religion, Vol. 39, Issue 1, pp. 78-90. 103

Edward, M., George, B. P., \& Sarkar, S. K. (2010). The impact of switching costs upon the service qualityperceived value-customer satisfaction-service loyalty chain: a study in the context of cellular services in India. Services Marketing Quarterly, (31)2, 151-173.

Evanschitzky, H., \& Wunderlich, M. (2006). An examination of moderator effects in the four-stage loyalty model. Journal of Service Research, (8)4, 330-345.

Ehikwe, A. (2005). Advertising and other Promotional Strategies, Enugu: Precision Publishers Limited. Exploratory Study, Journal of Marketing, (59), 71-82.

Fournier, S. (1998).Consumers and their Brands: Developing Relationship Theory in Consumer Research'. Journal of Consumer Research, (24), 343-373.

Fraering, M., \& Minor, M. (2013). Beyond loyalty: customer satisfaction, loyalty, and fortitude. Journal of Services Marketing, (27)4, 334-344.

Grönholdt, et al. (2000).The Relationship Between Customer Satisfaction and loyalty: Cross-Industry Differences'. Total Quality Management, (11)4, 5-6.

Juwah, E. (2011), Driving investment in Nigerian telecommunication market, Nigerian Communication Commission.

Keller, K.. (2002), Branding and Brand Equity,; in Handbook of Marketing, eds, London Sage Publications.

Keller, K. (2001) Building Customer-Based Brand Equity. Marketing Management. New Jersey: Prentice Hall.

Keller, K. (2003) Strategic Brand Management: Building, Measuring and Managing Brand Equity, Journal of Marketing. (57)1, 1-221.

Kotler, P, \& Keller, K.. (2009). Marketing Management, 13e, Prentice Hall: Pearson International.

Kotler, P. \& Armstrong, G. (2010). Principles of marketing: Pearson education.

Kumar, P. (2002). The impact of performance, cost, and competitive considerations on the relationship between satisfaction and repurchase intent in business markets. Journal of Service Research, (5)1, 55-68.

Kuo, N., Chang, K., Cheng, Y., \& Lai, C. (2013). How service quality affects customer loyalty in the travel agency: The effects of customer satisfaction, service recovery, and perceived value. Asia Pacific Journal of Tourism Research, (18)7, 803-822.

Kuusik, A. (2007). Affecting customer loyalty: Do different factors have various influences in different loyalty levels? The University of Tartu Faculty of Economics and Business Administration Working (58-2007).

Lai, F., Griffin, M., \& Babin, B. (2009). How quality, value, image, and satisfaction create loyalty at a Chinese telecom. Journal of Business Research, (62)10, 980-986.

Lee, E., Park, S., Rapert, M., \& Newman, C. (2012). Does perceived consumer fit matter in corporate social responsibility issues? Journal of Business Research, (65)11, 1558-1564.

Lee, H. (2013). Major moderators influencing the relationships of service quality, customer satisfaction and customer loyalty. Asian Social Science, (9)2, 1-9

Luo, X., \& Bhattacharya, C. (2006). Corporate social responsibility, customer satisfaction, and market value. Journal of marketing, (70) 4, 1-18.

Lewitt, T. (1983). 'After the sale is over'. Harvard Business Review. 87-93..

Malik, M., Ghafoor, M., \& Hafiz, K. (2012). Impact of Brand Image, Service Quality and price on customer satisfaction in Pakistan Telecommunication sector. International Journal of Business and Social Science, (3)23. 
Minarti, S., \& Segoro, W. (2014). The Influence of Customer Satisfaction, Switching Cost and Trusts in a Brand on Customer Loyalty - The Survey on Student as im3 Users in Depok, Indonesia. Procedia-Social and Behavioral Sciences, (143), 1015-1019

Nebo, O. (2004). Marketing: Contemporary and Comprehensive Approach, Owerri: Roik Business Concerns.

Ogbuji, C. (2008). Branding a Strategic Marketing Tool in a Competitive Environment. Marketing in Contemporary Nigeria, Owerri: Stramark Communications Consult. 106

Okafor, A. (1998).The Practice of Marketing, Onitsha: Beset Publishers Limited.

Okpara, G. (2002), Contemporary Marketing: Topical and Tropicalised, Enugu: John Jacob‘s Classic Publishers Ltd.

Olakunori, K. (1999). Dynamics of Marketing, Enugu: M“cal Communications International.

Oliver, R. (1999). 'Whence Consumer Loyalty?'. Journal of Marketing, (63) 33-44.

Onah, J., \& Thomas, M. (2004), Marketing Strategies and Cases, 2e Enugu: Institute for Development Studies University of Nigeria. Persuasion', Journal of Marketing Research, (36)1, 45-58.

Phau, I., \& Lau, J.(2001). Brand Personality and consumer self-expression: Single or dual carriageway?, Journal of Brand Management (8 ) 428-444.

Reichheld, F.. (2003). The One Number You Need to Grow'. Harvard Business Review, (81)12, 46-55. .

Van, A. (2007). Building Iconic Brands, Available from Internet: http www.building iconicbrands.com. 